\author{
Ruslana RUSKA
}

\title{
EVALUATION POSITIONS OF CREDIT UNIONS IN THE WORLD MARKET OF FINANCIAL SERVICES
}

\begin{abstract}
Credit unions have been functioning on the financial market of Ukraine for more than twenty years, and necessity of their existence is still questionable. Imperfect system which controls credit unions in our country often leads to distorted activity. Investigating the uniqueness of the world credit unions and basic principles of their activity stipulated the necessity of a completely new approach to the evaluation of credit unions positions in the world market of financial services. Due to the analysis of penetration it is educed that credit unions embrace a substantial financial market share on different world continents. A cluster analysis revealed that credit unions with the similar functions belong to the same cluster. After investigation of management monitoring systems of credit unions in different countries it has been established that these systems are rather «ex»/ «post» indicators of the present credit unions problems. Relations between regulators and credit unions are of different types. "Three Bucket Approach» methodology for credit unions and theoretical aspects of the methodology, which involves reserve formation on loans and its application have been considered.
\end{abstract}

(C) Ruslana Ruska, 2017.

Ruska Ruslana, Cand. of Economic Sciences, Ternopil National Economic University, Ukraine. 


\section{Key words:}

Financial system, credit unions, cluster analysis, multidimensional adaptive splines, penetrations, control system, model, «Three Bucket Approach» methodology, loans, backlogs.

JEL: C40 C80 E44 F37 O50.

\section{Problem setting (actuality)}

Credit unions, modern microcredit establishments that successfully operate and develop, have become the most widespread variety of unprofitable financial institutions in the world. Experience of the world countries proves that credit unions occupy the proper place in the financial systems of the both developed and developing countries of all continents. They take an important place on the market of financial services, and also in its credit system. Basic activity of credit unions is granting loans which predetermine a requirement for forming reserve.

\section{Literature review}

Issues relating to foreign experience of credit unions studied by L. I. Babydorych (Babydorych, 2014, pp. 169-173). Problems of regulation of credit unions researched in the works of O. V. Dobrovolska (Dobrovolska, 2015) and A. V. Khomutenko (Khomutenko, 2009), the scientists B. M. Komarnytskyi and M. D. Muzhylivskyi are exploring cooperative model in which credit unions operate in the world (Komarnytskyi, Muzhylivskyi, 2010). A. O. Prudnikov focuses on study of credit unions management (Prudnikov, 2014, 110-113). The researchers V. V. Honcharenko, O. L. Klymko and A. A. Pozhar in their works focus mainly on the effective use of foreign experience of credit unions for domestic credit unions (Honcharenko et al., 2010, pp. 233-234). However, the uniqueness of credit unions as cooperative and financial institutions still requires further investigation. 


\section{Purpose}

The aim of the research is to conduct a complex analysis of the modern credit unions in the world and improve the approach to the evaluation of credit unions position in the global financial services market.

\section{4 .Results}

Last decade has witnessed a dynamic growth and development of credit unions in the world. According to data of WOCCU (World Council of Credit Unions) there are more than 60 thousand credit unions in the world in 105 countries (table 1).

Table 1

Worldwide Credit Unions Development

\begin{tabular}{|c|c|c|c|c|c|c|c|}
\hline$\stackrel{\bar{\varpi}}{\stackrel{\bar{\varpi}}{\succ}}$ & 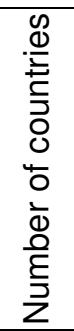 & 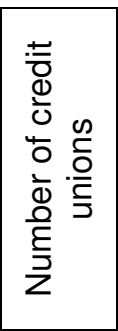 & $\begin{array}{l}\text { Number } \\
\text { of CU } \\
\text { members }\end{array}$ & $\begin{array}{l}\text { Savings } \\
\text { (thousand } \\
\text { \$ USA) }\end{array}$ & $\begin{array}{l}\text { Loans } \\
\text { (thou- } \\
\text { sands } \\
\text { \$ USA) }\end{array}$ & $\begin{array}{c}\text { Re- } \\
\text { serves } \\
\text { (thou- } \\
\text { sands } \\
\text { \$ USA) }\end{array}$ & $\begin{array}{c}\text { Assets } \\
\text { (thousands } \\
\text { \$ USA) }\end{array}$ \\
\hline 2006 & 96 & 46367 & 172007510 & 904120858 & 758208659 & 106825743 & 1092135905 \\
\hline 2007 & 96 & 49134 & \begin{tabular}{|l|}
177383728 \\
\end{tabular} & 987861248 & 847896069 & 115358461 & 1181465915 \\
\hline 2008 & 97 & 53689 & 185800237 & 995741235 & 847058749 & 115316544 & 1193811863 \\
\hline 2009 & 97 & 49330 & 183916050 & 1145851168 & 911752609 & 119738181 & 1352633626 \\
\hline 2010 & 100 & 52942 & 188681967 & 1126413429 & 959717897 & 131716614 & 1459694183 \\
\hline 2011 & 100 & 51013 & 196498738 & 1221635067 & 1016243687 & 14131 & 1563529230 \\
\hline 2012 & 101 & 55952 & 200243841 & 1293256192 & 1083818986 & 161810294 & 1693949441 \\
\hline 2013 & 103 & 56904 & 207935920 & 1433306753 & 1135173182 & 171626687 & 1732945830 \\
\hline 2014 & 105 & 57480 & 217373324 & 1470863017 & 1202039908 & 181447651 & 1792935093 \\
\hline 2015 & 105 & 60645 & 222798027 & 1507944065 & 1242397017 & 185287266 & 1823329066 \\
\hline 2016 & 124 & 60785 & 222798028 & 1507944065 & 1224397118 & 185287266 & 182332991067 \\
\hline
\end{tabular}

* Source: compiled by the author using WOCCU data (Electronic resource) 
Analyzing the results of credit unions development in the world, it is necessary to admit steady increase of basic indexes. Not only have there been the increase of assets but also number of members of credit unions, what proves steady system development of this sector of financial market and increase of trust of consumers to them. Trust to credit unions shows penetration which WOCCU has been using since 2015.

To understand the factors that contribute to the development of credit unions in these countries we will use the module Multivariate Adaptive Splines (MARSPline) which is used in Data Mining and the program Statistics (Sutnik, Krasnjk, 2007).

The task of regression in our case is to identify the relationships between the dependent variable (penetration) and independent variables: the ratio of credit union members of the economically active population aged 15 to 64 years.

Research of influence of the chosen factors on penetration of credit unions for 105 countries of the world WOCCU members (fig. 1) shows the regions with the biggest number of credit unions.

Most penetration is observed in North America and the least is in Europe (3.4\%). This is because of recent popularity of credit unions in Eastern Europe and we have not included here continental Europe as credit cooperatives emerged here not as a separate group of financial institutions but as part of the credit unions.

Considering the dynamic of credit unions penetration (Fig. 2), we can see its growth, which shows that credit unions have taken their niche in the financial services market.

As the penetration in different regions is not the same, the question is to determine whether countries with different models of credit unions management have common features of economic development.

Clustering us to distribute a group of countries into sub-groups i.e. clusters. Formed with the initial multidimensional data, homogeneous subsets reveal countries distribution within WOCCU.

In this case it is necessary to aggregate objects (countries) to form clusters for selected characteristics only if the object can only belong to one cluster. Characteristics of credit unions are the following: the number of credit unions, membership of credit unions, savings and loans and reserve assets. Using different algorithms of cluster analysis, we can conclude that the most significant in this case is to use the method of k-means which resulted in 6 clusters. Nonhierarchical clustering algorithm (division of a set of $n$ elements into clusters) $k$ means the following: choose $\mathrm{k}$ arbitrary initial center-point in space (centroids). Further, all objects are grouped into k -groups by proximity from the centroid. The next step is to determine the new cluster centroids which are repeated until the cluster centroids and boundaries between them cease to change. 
Fig. 1

A spline regressive surface of penetration of credit unions on continents

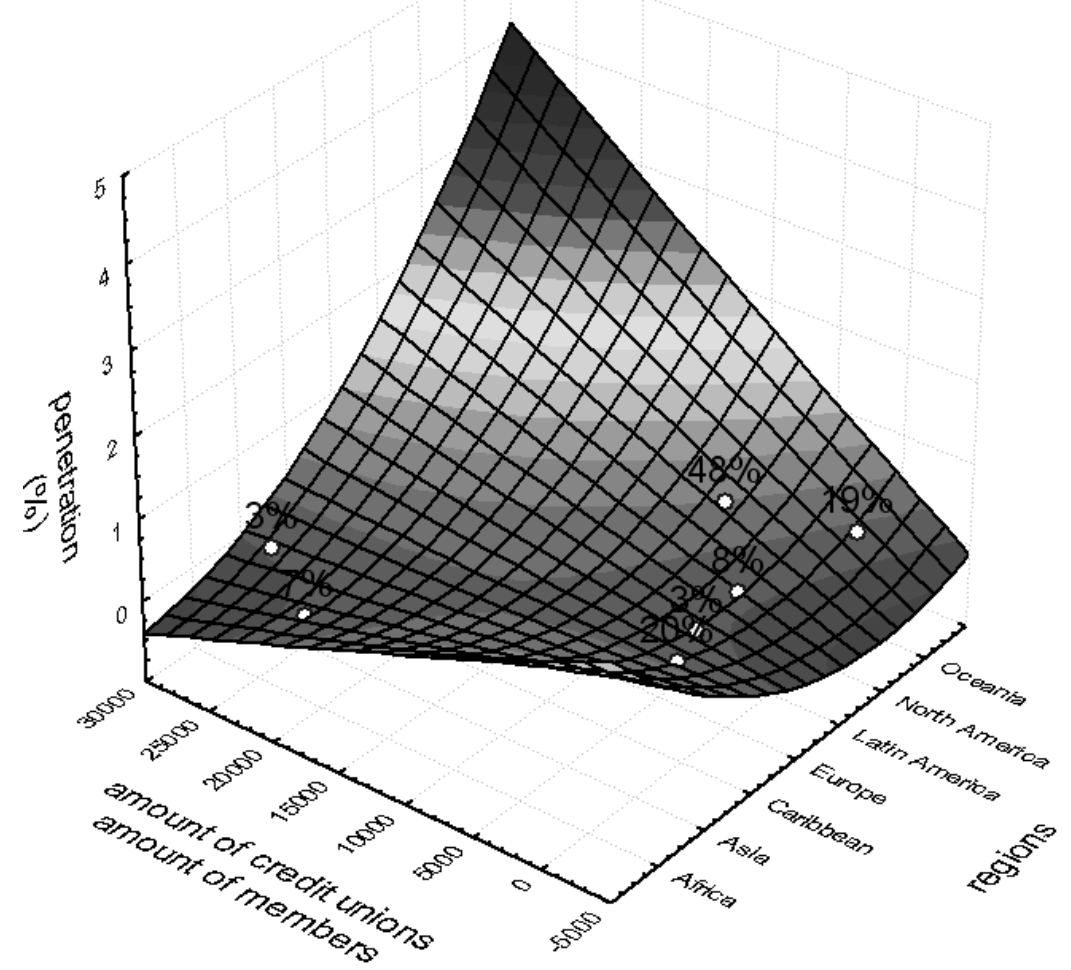

*It is compiled by the author based on (Electronic resource)

Using spline surface and clustering algorithm method with software application Statistics we have divided WOCCU member countries into six clusters (Figure 3). To ensure the performance of proportion we conducted their evaluation. The first cluster consisted of 10 countries, the second - 37 countries, the third -7 countries, the fourth -22 countries, the fifth -11 countries, and the sixth -28 countries. The third cluster includes countries where credit unions have just started their operation and do not have sufficient crediting.

The second largest cluster includes countries where credit unions perform a function of small banks, and which have been operating and developing over relatively long periods of time. In addition, deposits there are insured and the loans interest is low. 
Fig. 2

Dynamics of credit unions penetration

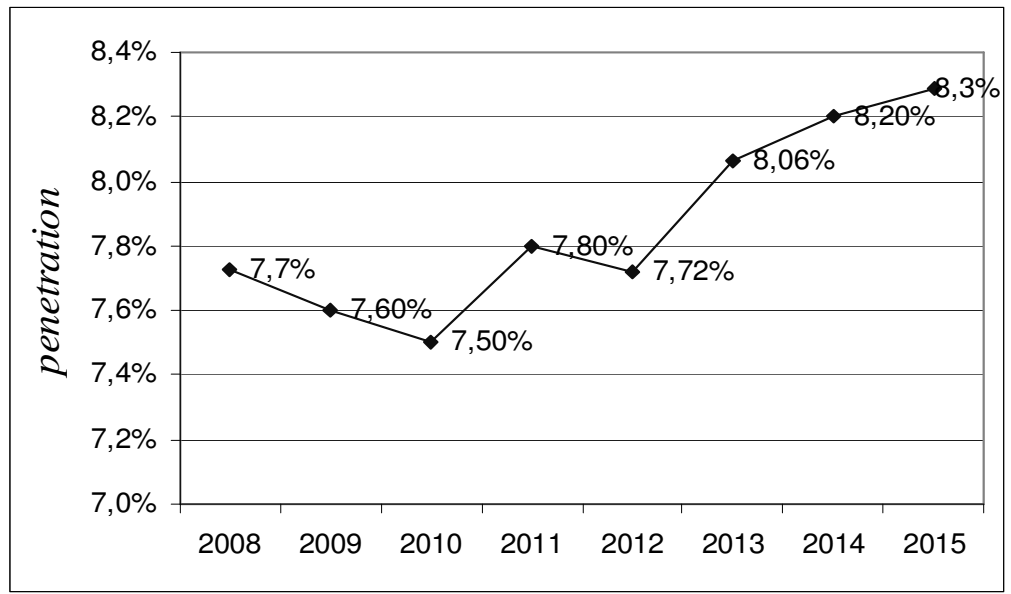

*Source: It is compiled by the author based on (Electronic resource)

Fig. 3

Spline clusters surface

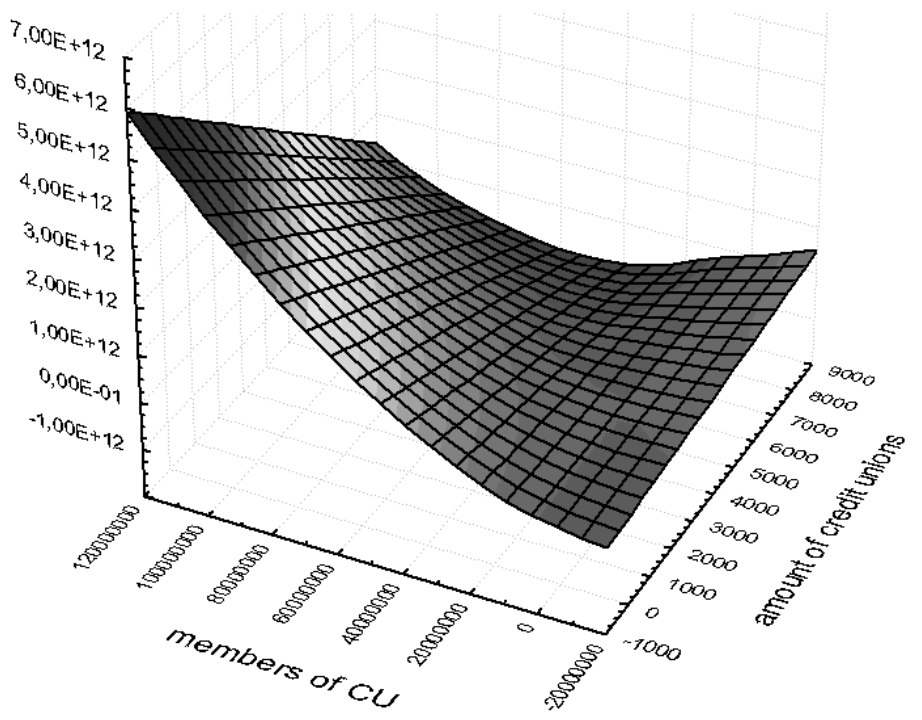

* Source: It is compiled by the author based on (Electronic resource) 

following:

The matrix of distances between the centers of the clusters looks like the

$$
\Delta=\left[\begin{array}{cccccc}
0 & 315,69 & 810,57 & 3693,18 & 802,61 & 443,77 \\
30,18 & 0 & 548,15 & 5725,13 & 224,491 & 1063,83 \\
68,51 & 82,01 & 0 & 7812,57 & 5637,13 & 4412,15 \\
28,33 & 14,98 & 81,47 & 0 & 5815,14 & 5412,16 \\
23,13 & 45,43 & 73,57 & 42,76 & 0 & 1828,51 \\
20,15 & 51,12 & 68,24 & 35,29 & 39,48 & 0
\end{array}\right] .
$$

The fifth cluster differs from the others as it mainly includes North American countries. Most countries of the cluster have the biggest average bound rate of interest on loans and deposits.

Thus, our cluster analysis indicates that the activities of credit unions in different countries are substantially different, and therefore at this stage more attention should be paid to their development and stable functioning.

Considering WOCCU country-members, it should be noted that credit unions of these countries organize their activities based on the developed Model Regulations regulating credit unions based on regulatory experience and best practices implemented in different WOCCU countries. Typical rules of regulation also include a set of financial indicators that characterize the credit unions reliability. In particular WOCCU recommends to use the most famous in the world ratings of local system evaluation: CAMELS - (classification of financial institution according to six components: Capital of adequacy; Asset of quality; Management; Earnings; Liquidity and bank's Sensitivity to market risk) (Dobrovolska, 2015; Electronic resource) and PEARLS (P (Protection); E (Effective Financial Structure); A (Assets Quality); R (Rates of Return and Costs); L (Liquidity); S (Signs) (Dobrovolska,2015; Electronic resource). KAPER includes the following indicators: capital adequacy (capital levels in general (general indicator of solvency), coverage of loans and loan capital, deposits capital covering, adequacy of capital in relation to risk of overdue and unpaid loans and credits, the level of reserve capital); asset quality (percentage of unprofitable assets, encumbrance of fixed assets, assets encumbrance by overdue loans, relation of loan portfolio to overdue payments); free reserve (the amount of free compulsory reserve, savings and loan turnover, total operating efficiency and current reserve); efficiency and profitability (Dobrovolska, 2015; Luzuschun, 2011, pp. 151-176).

These systems do not predict future financial condition of the credit unions and do not diagnose the likelihood of bankruptcy. So, in different countries different systems of risk evaluation and early warning are used (Table 2). These systems are used by the regulators of these countries. 
Table 2

The system of risks evaluation and early warning in some countries*

\begin{tabular}{|c|c|c|}
\hline Country & System & Description of the system \\
\hline \multirow{2}{*}{ France } & $\begin{array}{l}\text { ORAP (organization and ap- } \\
\text { plication of preventative ac- } \\
\text { tions) }\end{array}$ & $\begin{array}{l}\text { Distance system of the ratings } \\
\text { monitoring }\end{array}$ \\
\hline & $\begin{array}{l}\text { SAABA (system of support of } \\
\text { analysis of financial institu- } \\
\text { tion) }\end{array}$ & $\begin{array}{l}\text { A model of the early warning is the } \\
\text { system of losses expectation }\end{array}$ \\
\hline Germany & $\begin{array}{l}\text { BAKIS (informative } \\
\text { system BAKred) }\end{array}$ & $\begin{array}{l}\text { The system of financial coeffi- } \\
\text { cients and comparing to the similar } \\
\text { establishments groups }\end{array}$ \\
\hline Italy & PATROL & $\begin{array}{l}\text { Distance system of the monitoring } \\
\text { ratings }\end{array}$ \\
\hline $\begin{array}{l}\text { The Neth- } \\
\text { erlands }\end{array}$ & $\begin{array}{l}\text { RAST (instrument of support } \\
\text { of risks analysis) }\end{array}$ & $\begin{array}{l}\text { System of complex estimation of } \\
\text { financial risks }\end{array}$ \\
\hline $\begin{array}{l}\text { Great Brit- } \\
\quad \text { ain }\end{array}$ & $\begin{array}{l}\text { RATE (estimation of risks, in- } \\
\text { struments of supervision and } \\
\text { assessment) }\end{array}$ & $\begin{array}{l}\text { System of complex estimation of } \\
\text { risks }\end{array}$ \\
\hline \multirow{3}{*}{ USA } & CAMELS & $\begin{array}{l}\text { The system of the ratings monitor- } \\
\text { ing by places inspections }\end{array}$ \\
\hline & SEER & $\begin{array}{l}\text { A model of the early warning is a } \\
\text { rating estimation and bankruptcy } \\
\text { prediction }\end{array}$ \\
\hline & $\begin{array}{l}\text { GMS - System of increase } \\
\text { monitoring }\end{array}$ & $\begin{array}{l}\text { A simple model of the early warn- } \\
\text { ing is watching of large increase of } \\
\text { financial institutions }\end{array}$ \\
\hline Poland & KAPER & Model of the early warning \\
\hline
\end{tabular}

* Source: (Luzuschun, 2011, pp. 151-176).

Relations between regulators and credit unions we define as intertype, i.e. we classify them as the following:

- identical (common perception of problems and their decisions, partner relations);

- dual (addition, developing a similar system for evaluating phenomena, events, values); 
- activation (relationships, although they are built on activities from time to time require distance provided there are increased tensions and independence defense);

- mirror (fruitful relations caused by the different approaches to understanding the situation);

- business (relations of equal partners);

- mirage (aspirations of partners are incomprehensible and contradictory with unreal aims);

- quasi identical (a lot of common perception, but different attitude toward values);

- conflict (complete opposition and conflict);

- superego relations (relations and large distance);

- relationship of complete opposition;

- relationships of control (asymmetric relations).

Cooperation between regulators and credit unions has a combined manifestation of the relationship, as the case of decisions, or depending on a taken decision or the interests and needs of the main participants.

All of the above methods are directed to the diagnosis of the current state of credit unions through the analysis of their operations and reporting data. Statistical models are used for evaluation of the future activity that allows to generate early warnings before the critical moment. Prediction for the future can be made considering the number of different factors using previous statistics data.

The technique of «Three Bucket Approach» has become interesting (after 2008 crisis modern banks use «Three Buckets Strategy « when the credits are divided into 3 groups (buckets, slang banking language), and in 2016 WOCCU proposed to use it for credit unions) under which it is necessary to create reserves for unpaid problem loans dividing them into three groups:

Group of loans with identical payment deadlines 1: (A group of loans with similar risk): loans without credit impairment, loans that are never overdue for more than 30 days. Group 1 recognizes expected losses over the next 12 months.

Group of loans with identical payment deadlines 2. (A group of loans with similar risk): loans without credit impairment i.e. loans are overdue for not more than 30 days at least, once (even if repaid later), but do not qualify for group 3. Group 2 recognizes the expected losses. 
Group of loans with identical payment deadlines 3 . (A group of loans with similar risk): loans with serious credit impairment, as well as a long history of unpaid dividends. Group 3 recognizes long-term losses (Electronic resource).

Bail and guarantors can be used to provide loans for the first two groups, in the third type of problem each loan should be considered individually.

We will illustrate the example from the first group, where $i$ - the number of different types of loans in the current period $n$, then the first group reserve is calculated as the following:

$$
R_{1}=\sum_{i=1}^{n} d_{i} e_{i} b_{i}
$$

where: $d_{i}-\%$ of repaid $i$-type problem loans for the latest period;

$e_{i}-\%$ of $i$-type problem loans for the current period;

$b_{i}$ - total face value of $i$-type loans for the current period.

If the second group includes $j$ - the number of different types of loans in the current period $n$, then a reserve for the second group is calculated by the formula:

$$
R_{2}=\sum_{j=1}^{n} e_{j} b_{j}
$$

where: $e_{j}-\%$ of $j$-type problem loans for the current period;

$b_{j}-$ total face value of $j$-type problem loans for the current period.

If in the third group $k$ with the number of different types of loans in the current period $n$, then reserve for the second group is calculated by the formula:

$$
R_{3}=\sum_{k=1}^{n} e_{k} b_{k},
$$

where: $e_{k}-\%$ of $k$-type problem loans for the current period;

$b_{k}-$ total face value of $k$-type problem loans for the current period.

Problem loans can change groups, so the loans of the first group can move to the second and vice versa and from the second to the third and back.

To calculate the reserve for each group we will use Table 3 and MARSPline module that gives an opportunity to show the function of regression with weighted sums member containing derivatives of the basic functions. 
Table 3

The study sample performance indicators of a conventional credit union

\begin{tabular}{|c|c|c|c|}
\hline $\begin{array}{c}\text { Reserves } \\
\text { thousands }\end{array}$ & $\begin{array}{c}\text { \% problem loans for } \\
\text { the current period }\end{array}$ & $\begin{array}{c}\text { \% written-off loans for } \\
\text { the previous period }\end{array}$ & $\begin{array}{c}\text { Total face value of } \\
\text { problem loans }\end{array}$ \\
\hline 3182 & 2,06 & 1,88 & 974 \\
\hline 4788 & 2,09 & 0,16 & 1783 \\
\hline 2437 & 15,1 & 4,34 & 2716 \\
\hline 3906 & 5,41 & 1,55 & 1749 \\
\hline 4320 & 15,13 & 12,82 & 1345 \\
\hline 2992 & 18,34 & 4,8 & 7041 \\
\hline 2307 & 35,53 & 9,14 & 7330 \\
\hline 4374 & 29,03 & 17,34 & 3496 \\
\hline 2894 & 29,94 & 9,9 & 5057 \\
\hline 1646 & 69,17 & 11,63 & 8058 \\
\hline 2080 & 46,49 & 9,68 & 8517 \\
\hline 2240 & 61,77 & 14,71 & 5984 \\
\hline
\end{tabular}

This module is a generalization of the methods that Friedman suggested for solving regression problems and is nonparametric procedure without assumptions about the overall appearance of functional relationships between dependent and independent variables.

MARSPline method enables to get meaningful model of sufficiently accurate predictions, even if the relationship between the dependent and predicted variables is monotonic. The algorithm in the space of all variables searches all nodal points and establishes relationships between variables.

Search of basic functions is carried out until the general criterion of the smallest squares fitting is maximized (Kulldorff, 1997, 1481-1496).

We will consider the first group of loans that were in debt for less than thirty days. Applying the module MARSPline we received the surface (Figure 4). It shows that the more unpaid problem loans were reported for the previous and current reporting periods the bigger reserve should be formed.

At the same time the graph shows that the peak reserve value (unreal in this case) is possible at an extremely high percentage of problem loans not only in the current period but in the previous as well, since outstanding loans from the previous period aggravate and strongly influence the formation of the first group reserve and lead to its increasing and this group can move to the second loans group. 
Fig. 4

Partial spline dependence of reserve formation (percentage of the repaid problem loans for the latest period, percentage of problem loans for the current period, total face value of the problem loans for the current period)
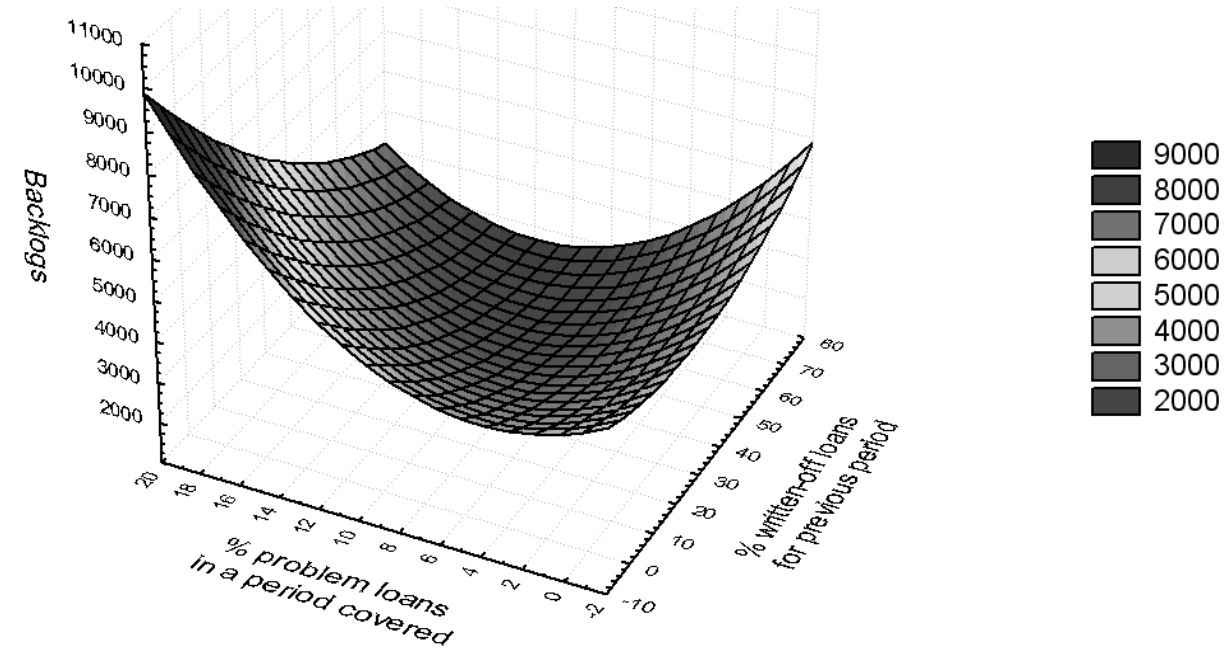

Multifactorial regression equation made it possible to determine the function of reserve formation for the first group:

$$
R_{1}=4208,9+0,185 x-31,98 x-215,3 y+0,49 x^{2}-3,86 x y+22,08 y^{2} .
$$

Assuming that the percentage of problem loans is $52 \%$ with the nominal value of 700 thousand dollars, then to form a first group reserve we need the reserve of $10,671,277$ s.u.

We will trace the impact of the selected factors for the study in Table 3 without taking into account the percentage of unpaid loans in the previous reporting period, belonging to the second group of loans which were overdue at least once.

As the partial spline surface shows (Fig. 5), the reserve for the second group depends on the share of problem loans and the nominal value. The smaller face value means the more stable reserve, i.e. interest loans for the second group should not be high and in this case the loans will remain in the group or move to the first group. 
Fig. 5

Partial spline dependency of the reserve (percentage of problem loans in the reporting period, the total nominal value of problem loans in the reporting period)

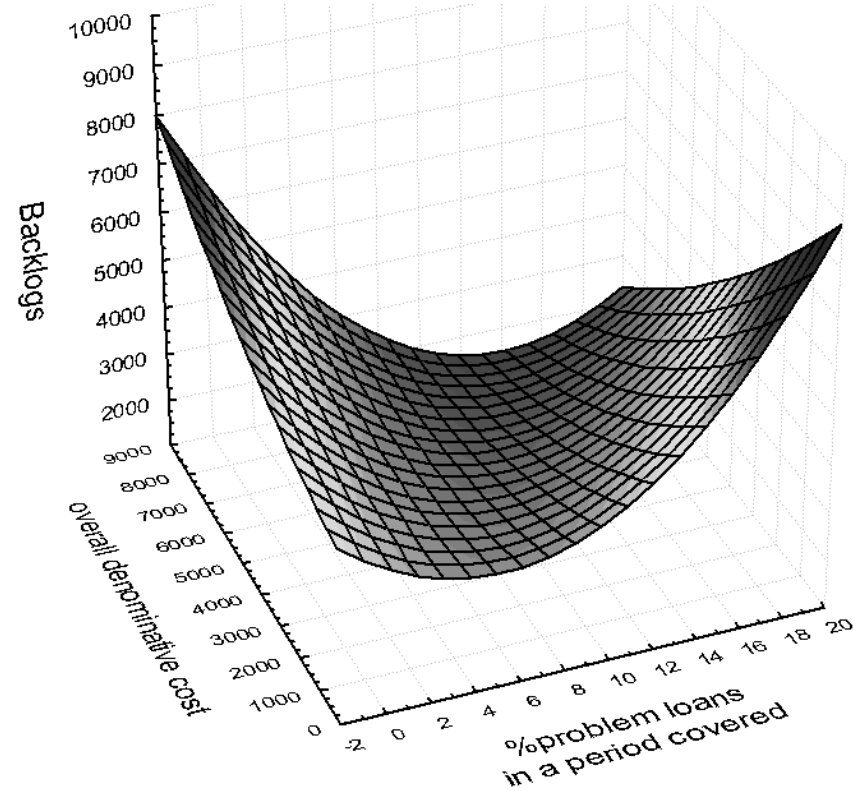

However, the impact of the percentage of problem loans in the group on the reserve is noticeable, i.e. the greater the percentage of loans is the bigger reserve for the second group should be. In addition, there is the likelihood of loans transfer to the third group, which may cause unstable operation of the credit union.

For the second group regressive equation is the following:

$$
R_{2}=4018,4-259,2 x+0,061 y+25,02 x^{2}-0,05 x y+0,0002 y^{2} .
$$

Assuming that the percentage of problem loans is $34 \%$ with the nominal value of 420 thousand dollars, then to form a reserve of the second group it is necessary to form a reserve of 3955.172 thousand s.u. 
Fig. 6

Partial spline reserve dependency (percentage of problem loans in the reporting period, the total nominal value of problem loans in the reporting period)

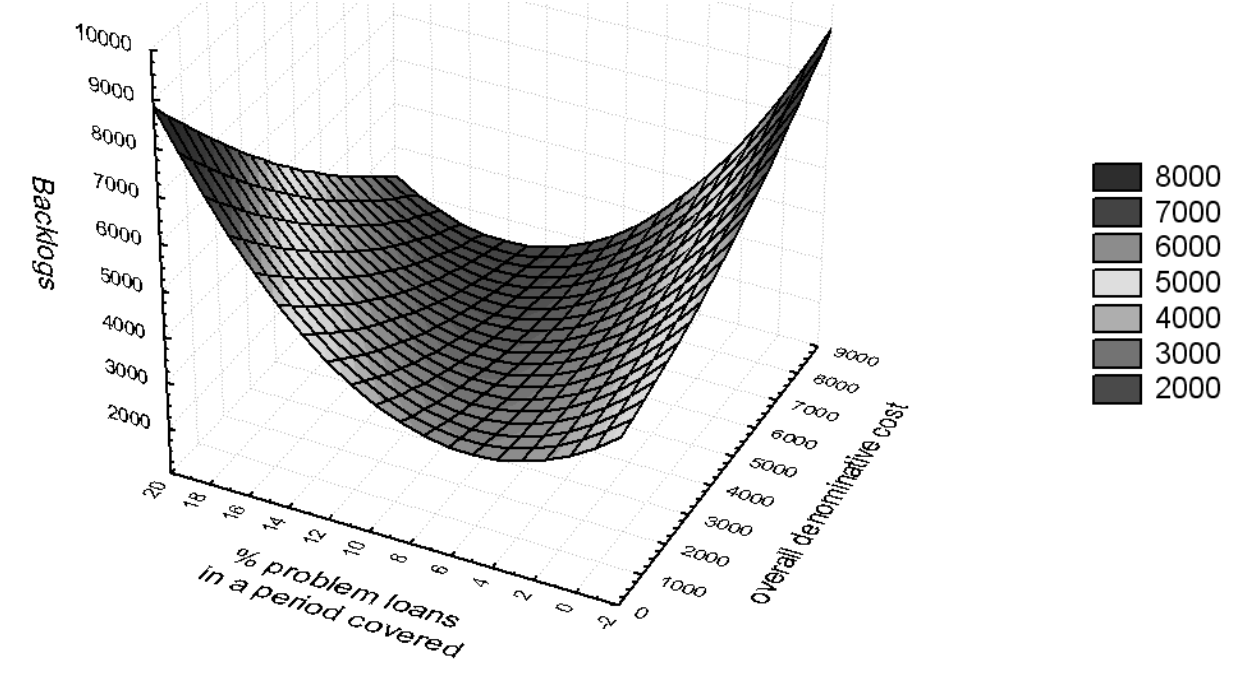

A similar situation is in the third group, the difference is in the increased nominal value which leads to the necessity of reserve increase. The percentage of problem loans does not play a significant role, since each of the group of loans should be considered individually.

The spline surface shows that the average percentage of problem loans will provide more or less stable nominal value, which in turn regulates the reserve of the third group.

Assuming that the loans belong to the third group, in other words they are not secured and with the high probability of loan defaults (data in Table 3), the equation will be the following:

$$
R_{3}=4018,4+0,06 x-259,2 y+0,00002 x^{2}-0,05 x y+25,02 y^{2} \text {. }
$$

If percentage of problem loans is $14 \%$ with the nominal value of 110 thousand dollars, then to form a third group reserve it is necessary to reserve 3988.674 s.u. and the reserves in three groups will amount their total. 


\section{Conclusions}

The study allows assuming that in the developed financial world, credit unions have a high penetration rate, i.e. the majority of the population uses their services.

Cluster analysis confirms that the respective clusters comprise credit unions from the countries with approximately the same level of economic development.

The effectiveness of the credit unions management systems worldwide has been analyzed. Every of the management systems has been characterized and it has also been determined that the relationship between regulators and credit unions are intertype.

Using «Three Bucket Approach» technique a reserve of a conventional credit union according to three groups of loans has been specified. We believe this method will be more complete to determine the reserve if all additional components, which form a pool of credit unions, are considered.

\section{References}

1. Babydorych, L. (2014). «Prospects to development of home credit unions on the base of European experience», The Scientific announcer of the Kherson state university, no. 6. Part 4, pp. 169-173.

2. Dobrovolska, O. (2015). «International experience and standards of adjusting of activity of credit unions", The Global problems of economy electronic scientific professional edition of the Mykolaiv national university the name of V.O.Suchomlunskogo [Electronic resource], it is access Mode: http://global national.in.ua /component/content/article/ 15-vipusk-7-veresen-r/1312- obrovolska - o-v- mizhnarodnij - dosvid - ta - standarti - regulyuvannya - diyalnosti - kreditnikh - spilok

3. Khomutenko, A. (2009). «International experience of organization of financial control in the system of credit unions", Forming of market relations in Ukraine, № 11, pp. 122-127.

4. Komarnytskyi, B., Muzhylivskyi, M. (2010). «The Use of world experience of activity of credit unions for activation of credit-co-operative motion in Ukraine», Announcer of University of banking of the National bank of Ukraine, March 1 (7), pp. 185-189. 
5. Prudnikov, A. (2014). «Comparative analysis of the system of credit unions of Ukraine, United States America and Canada», Young scientist, № 4 (07), pp. 110-113.

6. Honcharenko, V., Klymko, O., Pozhar, A. (2010). «International principles of activity of credit co-operative organizations", Announcer of the Donetsk national university of economy and trade. Series are «Economic sciences», № 4 (48), pp. 233-234.

7. An official web-site of World Advice of credit unions. Retrieved from: http://www.woccu.org/publications/statreport

8. Sutnik, V., Krasnjk ,M. (2007). Intellectual analysis of data. Manual. Kiev, KNEU (in Ukrainian).

9. Luzuschun, O. (2011). Credit unions at the market of financial services of Ukraine : cand. of economic of sciences . Ternopil: TNEU, pp. 151-176.

10. «Three Bucket Approach». World Council of Credit Unions. Retrieved from: http://www.woccu.org/WOCCUIFRS_9_for_Coop_Financial_Institutions_Dec _2016.pdf

11. Kulldorff, M.( 1997). A spatial scan statistic // Communications in Statistics. Theory and Methods, 26(6), pp. 1481-1496. 